\title{
DETERMINATION OF DEVELOPMENTAL AND LIFE TABLE PARAMETERS OF RHYZOBIUS LOPHANTHAE BLAISDELL (COLEOPTERA COCCINELLIDAE) ON THREE ARMORED SCALE INSECTS (HEMIPTERA DIASPIDIDAE) $\left(^{1}\right)$
}

\author{
(*) Süleyman Demirel University, Faculty of Agriculture, Department of Plant Protection, Isparta, Turkey \\ ( ${ }^{\circ}$ Corresponding author: ismailkaraca@sdu.edu.tr
}

\begin{abstract}
Şimşek B., Karaca İ., Kayahan A. - Determinatıon of developmental and life table parameters of Rhyzobıus lophanthae Blaisdell (Coleoptera Coccinellidae) on three armored scale insects (Hemiptera Diaspididae).

Scale insects are the most damaging pests of citrus production in Turkey. Rhyzobius lophanthae Blaisdell (Coleoptera: Coccinellidae), a polyphagous coccinellid, is one of the most important predators of these pests. In this study, the life tables of $R$. lophanthae on three different armored scale insects, Aonidiella aurantii (Maskell), Aspidiotus nerii Bouché, Chrysomphalus dictiyospermi (Morgan) (Hemiptera: Diaspididae), were produced. The study was conducted in a climate chamber under constant conditions of $26^{\circ} \mathrm{C}, 60 \%$ relative humidity and 16 -hour photoperiod

The net reproductive rate $\left(R_{0}\right)$, intrinsic rate of increase $\left(\boldsymbol{r}_{\boldsymbol{m}}\right)$ and mean generation time $\left(T_{0}\right)$ were $36.027,12.520$ and $6.600 \mathrm{females} /$ female/generation, $0.120,0.061$ and $0.041 \mathrm{females} / \mathrm{female} / \mathrm{day}$, and 30.005, 41.151, 45.826 days, respectively, when $R$. lophanthae was reared on A. nerii, C. dictiyospermi and A. aurantii, respectively. The doubling time (DT) and finite rates of increase ( $\lambda$ ) were 5.803, 11.286 and 16.832 days, 1.127, 1.063 and 1.042 individuals/female/day, respectively, when $R$. lophanthae was reared on A. nerii, C. dictiyospermi and A. aurantii, respectively.
\end{abstract}

Key Words: Aonidiella aurantii, Aspidiotus nerii, Chrysomphalus dictiyospermi, life table, Rhyzobius lophanthae.

\section{INTRODUCTION}

Fruit and vegetable production is an important segment of world agriculture. Citrus fruits are considered some of the most important due to the huge production area and commercial value. Originating from China, India and SouthEast Asia, citrus is now grown throughout areas with a temperate climate (AKGÜN, 2006). In Turkey, citrus production is approximately 3.7 million tonnes annually (FAO, 2013).

Among the many pests of citrus, scale insects cause significant economic losses everywhere that citrus is grown. Aonidiella aurantii (Maskell), Aspidiotus nerii Bouché and Chrysomphalus dictiyospermi (Morgan) (Hemiptera: Diaspididae) feed and cause damage on citrus fruits. In addition, $A$. aurantii infestation damages the trunk, branches and shoots (UYGUN et al., 2013).

Chemical control of scale insects on citrus is very difficult due to the wax these pests. Therefore, comprehensive studies have been carried out recently to develop biological control methods against these armored scale pests. One of the most effective predators is the coccinellid, Rhyzobius lophanthae Blaisdell (Coleoptera: Coccinellidae) (STATHAS et al., 2002).

This study examined the development and life table parameters of $R$. lophanthae when reared on three armored scale species, $A$. aurantii, $A$. nerii and $C$. dictiyospermi. The ultimate goal of this study was to identify the armored scale species on which $R$. lophanthae could be most efficiently reared.

\footnotetext{
${ }^{1}$ Original scientific contribution presented and discussed at XIV International Symposium on Scale Insect Studies, Catania-Italy, 13-16 June 2016.
}

\section{MATERIALS AND METHODS}

PREY SOURCE

The scale insects which were used as the prey in this study were obtained from a laboratory colony at Süleyman Demirel University in Isparta, Turkey, with production in weekly periods throughout the study. Aspidiotus nerii was produced on potato tubers (Solanum tuberosum L.) (Solanaceae), and infestation was initiated by putting potatoes infested with $A$. nerii next to clean potatoes. Chrysomphalus dictiyospermi and Aonidiella aurantii were produced on pumpkins (Cucurbita moschata Duch.) (Cucurbitaceae), and infestation was achieved by placing pumpkins infested with $A$. aurantii next to clean pumpkins.

\section{SOURCE OF RHYZOBIUS LOPHANTHAE}

Rhyzobius lophanthae individuals, collected from citrus orchards in Adana Province in southern Turkey with the shaking method of STEINER (1962), were used to establish a laboratory colony at the Biological Control Research and Application Laboratory of the Department of Plant Protection, Süleyman Demirel University, Isparta, Turkey. The conditions in the climate chamber were set at $25 \pm 1{ }^{\circ} \mathrm{C}$, $65 \pm 5 \%$ relative humidity and long-day lighting (16 h: $8 \mathrm{~h}$ ). Rhyzobius lophanthae individuals were taken from this stock culture for experimental purposes.

\section{EXPERIMENTAL DESIGN}

This study was conducted in a climate chamber at a temperature of $26 \pm 1^{\circ} \mathrm{C}, 60 \pm 5 \%$ relative humidity and longday lighting ( $16 \mathrm{~h}$ light: $8 \mathrm{~h}$ darkness). The day before the establishment of the experiment, 20-30 Rhyzobius lophanthae individuals that had emerged from pupae on the 
same day were placed on potato tubers infested with Aspidiotus nerii and deposited in a plastic container. After ten days, the eggs laid by $R$. lophanthae on these potato tubers were removed with a soft sable brush without damage for use in in this study.

Aspidiotus nerii was used as the prey in the first experiment in which infested potato tubers were placed individually in plastic containers $(10 \times 10 \times 5 \mathrm{~cm})$. One $R$. lophanthae egg was placed on each potato tuber with a soft brush. Aonidiella aurantii and C. dictiyospermi were used as the prey in the second and third experiments in which infested pumpkins were placed individually in plastic containers $(20 \times 13.5 \times 10)$. One $R$. lophanthae egg was placed on each pumpkin with a soft brush. $R$. lophanthae individuals, reared on the three different preys to the adult stage, were observed daily under a stereomicroscope (Leica S6D, x10 magnification) to determine their developmental periods.

Individuals were separated into males and females after developing into adults (STATHAS et al., 2002). After this process, one male and one female $R$. lophanthae were placed in each plastic container for the three different groups. Then, the eggs produced by these individuals were counted daily. This process continued until all adult individuals had died so that life tables of females of $R$. lophanthae were able to be calculated for the 3 different preys.

The data from the experiments were used to develop agerelated life tables for each prey used. All parameters in the life table were calculated with the Euler-Lotka equation (BIRCH, 1948) by using RmStat-3 (ÖZGÖKÇE \& KARACA, 2010).

Parameters used for calculations:

Age-related survival rate $\left(l_{x}\right)$ and fertility rate $\left(m_{x}\right)(\mathrm{BIRCH}$, 1948);

Net production rate, (BIRCH, 1948);

$$
R_{0}=\sum l_{x} \cdot m_{x}
$$

Intrinsic rate of increase $\left(r_{m}\right)$, (BIRCH, 1948)

$$
\sum e^{\left(-r_{m} x\right)} l_{x} \cdot m_{x}=1
$$

Mean generation time, (BIRCH, 1948)

$$
T_{o}=\frac{\ln R_{0}}{r_{m}}
$$

Total productivity rate, $(\mathrm{BIRCH}, 1948)$

$$
G R R=\sum m_{x}
$$

Daily maximum reproductive value, (BIRCH, 1948)

$$
\lambda=e^{r_{m}}
$$

Doubling time, (KAIRO and MURPHY, 1995),

$$
T_{2}=\frac{\ln 2}{r_{m}}
$$

Reproductive value, (IMURA, 1987).

$$
V_{x}=\frac{\sum_{y=x}\left(e^{r_{m} \cdot y} \cdot l_{y} \cdot m_{y}\right)}{l_{x} \theta^{-r_{m} x}}
$$

The pseudo-rmij values were calculated with the Jackknife method (MEYER et al., 1986; ÖZGÖKÇE \& ATLIHAN, 2004) to include the use of intrinsic rate of increase values calculated for these populations in comparison tests. Furthermore, the developmental periods of immature stages for each prey were evaluated separately. The Tukey multiple comparison test was then used for the comparison of these with SPSS (ver. 17) program. The significance difference was set at $\mathrm{p}<0.05$.

\section{RESULTS AND DISCUSSION}

The development period of the egg stage of $R$. lophanthae fed on three different prey was not significantly different $(\mathrm{F}=0.68, \mathrm{df}=3, \mathrm{P}=0.507)$. The first stage of $R$. lophanthae fed on $A$. nerii developed more rapidly than those fed on the other two armored scale species $(\mathrm{F}=119.02$, $\mathrm{df}=3, \mathrm{P}=0.0001$ ). The second larval stage of $R$. lophanthae fed on $A$. nerii also showed more rapid development than those fed on the other armored scale insect species $(\mathrm{F}=24.85, \mathrm{df}=3, \mathrm{P}=0.0001)$. For the third stage, while the larvae of $R$. lophanthae fed on $A$. nerii developed more rapidly than on other two species, larvae of $R$. lophanthae fed on $C$. dictiyospermii developed faster than when fed on A. aurantii $(\mathrm{F}=28.48, \mathrm{df}=3, \mathrm{P}=0.0001)$. Results for the fourth larval stage were similar to the third larval stage. Overall, the larvae of $R$. lophanthae fed on A. nerii developed more rapidly than on the other two species, and larvae of $R$. lophanthae fed on $C$. dictiyospermii developed faster than on A. aurantii $(\mathrm{F}=32.66, \mathrm{df}=3, \mathrm{P}=0.0001)$. Larvae of $R$. lophanthae fed on $A$. nerii developed more rapidly than those fed on $C$. dictiyospermii $(\mathrm{F}=33.13, \mathrm{df}=3, \mathrm{P}=0.0001)$. For total development times, larvae fed with $A$. nerii developed more rapidly than those fed on A. aurantii and $C$. dictiyospermii $(\mathrm{F}=166.08, \mathrm{df}=3, \mathrm{P}=0.0001)$ (Table 1$)$.

STATHAS (2000) investigated the development of $R$. lophanthae at different temperatures and with $A$. nerii as the prey. The development times of all stages (larval, pupal and total time) of $R$. lophanthae were longer than in our study. However, for the other preys in our study, the development times of all stages of $R$. lophanthae were shorter. When this study was compared with the literature (STATHAS, 2000), the development times of immature stages of the individuals fed with $A$. nerii was different. This could have resulted from the difference of the temperatures at which the study was carried out. Stathas et al. (2002) examined the development of $R$. lophanthae at four different temperatures under laboratory conditions, with Chrysomphalus aonidum L. as the prey. In our study, all stages of $R$. lophanthae fed on $A$. nerii developed more quickly than $C$. aonidium in their study. When the total development times were analyzed, it was determined that all three prey used in the present study developed in a shorter time than $C$. aonidium. When the development times of the immature stages of $R$. lophanthae from the two studies were compared, there were some differences. These may have resulted from the difference of the temperature at which the study was carried out and also the prey.

NAR et al. (2009) investigated the effects of $25^{\circ} \mathrm{C}$ temperature on the development of $R$. lophanthae fed on $A$. nerii. The development times of all stages (larval, pupal and total time) of $R$. lophanthae were slower than in our study. A difference was also seen between the development periods of the immature stages of the individuals fed with $C$. dictiyospremi and A. aurantii in the current study and reported by NAR et al. (2009). When the development times of the immature stages of the individuals fed with $A$. nerii in our study were compared with the development periods in the literature (NAR et al., (2009), there were differences between periods. These differences may also have resulted from the different temperatures used.

In this study, the preoviposition periods of $R$. lophanthae fed on A. nerii, C. dictiyospermi and A. aurantii were 3.7, 
Table 1 - Development times (days ) of the immature stages of Rhyzobius lophanthae fed on three different prey.

\begin{tabular}{|c|c|c|c|c|c|c|}
\hline \hline & $\mathbf{n}$ & Aspidiotus nerii & $\mathbf{n}$ & $\begin{array}{c}\text { Chrysomphalus } \\
\text { dictiyospermi }\end{array}$ & $\mathbf{n}$ & Aonidiella aurantii \\
\hline Egg & 64 & $4.17 \pm 0.088 \mathbf{a}$ & 52 & $4.21 \pm 0.069 \mathbf{a}$ & 50 & $4.30 \pm 0.071 \mathbf{a}$ \\
\hline Larva 1 & 42 & $2.57 \pm 0.085 \mathbf{a}$ & 34 & $5.65 \pm 0.211 \mathbf{b}$ & 37 & $5.89 \pm 0.218 \mathbf{~ b}$ \\
\hline Larva 2 & 36 & $2.08 \pm 0.047 \mathbf{a}$ & 28 & $2.79 \pm 0.107 \mathbf{b}$ & 28 & $3.18 \pm 0.179 \mathbf{b}$ \\
\hline Larva 3 & 33 & $1.88 \pm 0.072 \mathbf{a}$ & 26 & $3.04 \pm 0.188 \mathbf{b}$ & 23 & $3.74 \pm 0.283 \mathbf{~ c}$ \\
\hline Larva 4 & 22 & $3.05 \pm 0.154 \mathbf{a}$ & 19 & $5.21 \pm 0.330 \mathbf{b}$ & 10 & $6.50 \pm 0.500 \mathbf{c}$ \\
\hline Pupa & 20 & $3.65 \pm 0.109 \mathbf{a}$ & 12 & $6.75 \pm 0.329 \mathbf{c}$ & 9 & $5.11 \pm 0.564 \mathbf{~ b}$ \\
\hline Total development time & 20 & $17.45 \pm 0.256 \mathbf{a}$ & 12 & $27.50 \pm 0.609 \mathbf{b}$ & 9 & $28.11 \pm 0.841 \mathbf{b}$ \\
\hline
\end{tabular}

Different letters on the same line indicate a significant difference $(p<0.05)$

6.7 and 12.0 days, respectively, the oviposition periods were $30.5,12.8$ and 12.6 days, respectively, and the postoviposition periods were $3.4,4.1$ and 5.4 days, respectively. The adult longevities of $A$. nerii, $C$. dictiyospermi and $A$. aurantii were 37.6, 23.6 and 30.0 days, and the generation times were $22.35,36.2$ and 41.0 days, respectively. The number of eggs laid daily was 5.53, 5.16 and 2.75 eggs/female, respectively, and the total number of eggs laid was 201.75, 123.7 and 82.5 eggs/female (Table 2).

STATHAS (2000) examined the development of $R$. lophanthae on $A$. nerii and reported the development periods of the immature stages and preoviposition time of the adults at different temperatures. When compared with our study, the preoviposition time was longer. STATHAS et al. (2002) examined the development of $R$. lophanthae on $C$. aonidium at different temperatures. At $25^{\circ} \mathrm{C}$, the preoviposition time of $R$. lophanthae was $5.3 \pm 0.91$ days. In the present study, the preoviposition time of the females fed with $A$. nerii was shorter than in other study (STATHAs et al., 2002). When the other two preys ( $C$. dictiyospermi and $A$. aurantii) were compared with STATHAS et al. (2002), the preoviposition time of the individuals fed with $C$. aonidium was shorter in our study. These differences may be a consequence of the different temperature at which the study was carried out and also the prey.

NAR et al. (2009) investigated the effects of 5 different temperatures, including $25^{\circ} \mathrm{C}$, on the development of $R$. lophanthae. Compared with our study, they reported a shorter preoviposition period, and a longer oviposition period, while the postoviposition period was similar. These differences may have resulted from the difference in temperature.

In the present study, the intrinsic rate of increase values for $R$. lophanthae fed with $A$. nerii, $C$. dictiyospermi and $A$.

Table 2 - The mean development time of adult individuals of Rhyzobius lophanthae fed on three different preys after maturity.

\begin{tabular}{|c|c|c|c|}
\hline & Prey & $\mathrm{N}$ & Mean \pm SE \\
\hline \multirow{3}{*}{ Preoviposition time } & A. nerii & 20 & $3.7 \pm 0.19$ \\
\hline & C. dictyospermi & 10 & $6.7 \pm 0.50$ \\
\hline & A. aurantii & 8 & $12 \pm 0.27$ \\
\hline \multirow{3}{*}{ Oviposition time } & A. nerii & 20 & $30.5 \pm 1.77$ \\
\hline & C. dictyospermi & 10 & $12.8 \pm 0.63$ \\
\hline & A. aurantii & 8 & $12.63 \pm 0.57$ \\
\hline \multirow{3}{*}{ Postoviposition time } & A. nerii & 20 & $3.4 \pm 0.15$ \\
\hline & C. dictyospermi & 10 & $4.1 \pm 0.18$ \\
\hline & A. aurantii & 8 & $5.38 \pm 0.18$ \\
\hline \multirow{3}{*}{ Adult longevity(female) } & A. nerii & 20 & $37.6 \pm 1.81$ \\
\hline & C. dictyospermi & 10 & $23.6 \pm 0.72$ \\
\hline & A. aurantii & 8 & $30 \pm 0.42$ \\
\hline \multirow{3}{*}{ Generation time } & A. nerii & 20 & $22.35 \pm 0.13$ \\
\hline & C. dictyospermi & 10 & $36.2 \pm 0.36$ \\
\hline & A. aurantii & 8 & $41 \pm 0.71$ \\
\hline \multirow{3}{*}{ Number of eggs laid daily } & A. nerii & 20 & $5.53 \pm 2.25$ \\
\hline & C. dictyospermi & 10 & $5.16 \pm 0.40$ \\
\hline & A. aurantii & 8 & $2.75 \pm 0.07$ \\
\hline \multirow{3}{*}{ Total number of eggs } & A. nerii & 20 & $201.75 \pm 7.66$ \\
\hline & C. dictyospermi & 10 & $123.7 \pm 12.27$ \\
\hline & A. aurantii & 8 & $82.5 \pm 2.75$ \\
\hline
\end{tabular}


aurantii were $0.120,0.061$ and 0.041 females/female/day, respectively, the net production rates $\left(R_{0}\right)$ values were $36.027,12.250$ and 6.600 females/female/generation, respectively, and the mean generation time $\left(T_{0}\right)$ values were 30.005 , 41.151 and 45.826 days, respectively. Furthermore, the total production rate $(G R R)$ values were $125.542,65.111$ and 41.369 , respectively, the doubling time $\left(T_{2}\right)$ values were $5.803,11.286$ and 16.832 days, and the finite rates of increment were $1.127,1.063$ and 1.042 individuals/ female/day, respectively (Table 3 ).

The pseudo-rmij values calculated separately for each prey were analyzed with the Tukey multiple comparison test. The average pseudo-rmij value for $R$. lophanthae fed with $A$. nerii was significantly different from the average for those fed with other preys $(\mathrm{F}=32.01, \mathrm{df}=3, \mathrm{P}=0.0001)$ (Table 3).

STATHAS et al. (2005) examined the reproductivity of $R$. lophanthae on $A$. nerii at $25^{\circ} \mathrm{C}$ under laboratory conditions. They calculated total productivity, net production rate and intrinsic rate of increase. The intrinsic rate of increase $\left(r_{m}\right)$ calculated in our study was similar to that of Stathas et al. (2005). However, the net production rate $\left(R_{0}\right)$ was different from this study. NAR et al. (2009) investigated the effects of different temperatures on the development of $R$. lophanthae. Its life table parameters $\left(r_{m}, R_{0}, T_{2}\right.$ and $\left.T_{0}\right)$ were calculated, using $A$. nerii as the prey. The values for the individuals fed on $A$. nerii, $C$. dictiyospermi and $A$. aurantii in our study were different. The differences may have resulted from the prey difference.

The survival rate $\left(1_{\mathrm{x}}\right)$, fertility rate $\left(\mathrm{m}_{\mathrm{x}}\right)$ and reproduction value $\left(\mathrm{V}_{\mathrm{x}}\right)$ of $R$. lophanthae individuals fed on A. aurantii, $A$. nerii and $C$. dictiyospermi under laboratory conditions in the present study are given in Fig. I. On the first prey ( $A$. aurantii), the survival rate, which was 1.00 at the beginning, began to decrease from the $4^{\text {th }}$ day and was 0.02 at the end of the $61^{\text {st }}$ day, with the production value $\left(\mathrm{V}_{\mathrm{x}}\right)$ highest (32.28) on day 41. Rhyzobius lophanthae laid the maximum number of eggs on day 45 and produced 5.31 eggs on average. They stopped producing eggs on day 57 . On the second prey $(A$. nerii), the survival rate, which was 1.00 at the beginning, began to decrease from the $3^{\text {rd }}$ day and was 0.02 at the end of the $65^{\text {th }}$ day, with the reproduction value $\left(\mathrm{V}_{\mathrm{x}}\right)$ highest $(46.75)$ on day 24. Rhyzobius lophanthae laid the maximum number of eggs on day 26, produced 8.34 eggs on average and stopped laying eggs on day 62.On the third prey $(C$. dictiyospermi), the survival rate, which was 1.00 at the beginning, decreased from the $4^{\text {th }}$ day and was 0.02 at the end of the $55^{\text {th }}$ day. The reproduction value $\left(\mathrm{V}_{\mathrm{x}}\right)$ was highest (49.43) on day 38. Rhyzobius lophanthae laid the maximum number of eggs on day 41, produced 10.42 eggs on average, and stopped producing eggs on day 51 (Fig. I).

Based on the studies performed up to now, it is possible to say that $R$. lophanthae is one of the most important agents in biological control programs (STATHAS, 2000; 2001; Stathas et al., 2002; 2005; NAR et al., 2009). Also, the present study demonsrated that $A$. nerii can be used as a prey to conduct the mass production of $R$. lophanthae.

\section{ACKNOWLEDGEMENTS}

The authors thank the Research and Technology Department of Süleyman Demirel University in Isparta, Turkey for financial support for this project (Project number: 4176-YL2-14) and Gregory T. Sullivan of the University of Queensland in Brisbane, Australia for editing the English in an earlier version of this manuscript.

\section{REFERENCES}

AkgüN C., 2006 - Turunçgiller Sektör Profil. Dış Ticaret Şubesi Uygulama Servisi [Citrus fruits Industry Profile. Foreign Trade Branch Application Service]. Ankara (htp:/www.ito.org.tr/Dokuman/Sektor/197.pdf).

BIRCH L.C., 1948 - The intrinsic rate of natural increase of an insect population. - Journal of Animal Ecology, 17: 15-26.

DEEVEY E.S., 1947 - Life tables for natural populations. Quarterly Review of Biology, 22: 283-314.

ENKEGAARD A., 1993 - The poinsettia strain of the cotton whitefly, Bemisia tabaci (Hom.; Aleyrodidae), biological and demographic parameters on poinsettia (Euphorbia pulcherrima) in relation to temperature. - Bulletin of Entomological Research, 83: 535-546.

FAO, 2013 - Food and Agriculture Organization of the United Nations. http://faostat.fao.org/site/291/ default.aspx.

HANSEN D.L., BrodsGaARd H.F., ENKEgAARD A., 1999 Life table characteristics of Macrolophus caliginosus preying upon Tetranychus urticae. - Entomologia Experimentalis et Applicata, 93: 269-275.

IMURA O., 1987 - Demographic attributes of Tribolium freemani Hinton (Coleoptera: Tenebrionidae). - Applied Entomology and Zoology, 22 (4): 449-455.

Table 3 - The life table parameters of Rhyzobius lophanthae fed on three different preys.

\begin{tabular}{cccc}
\hline \hline Life table parameters & $\begin{array}{c}\text { Aspidiotus } \\
\text { nerii }\end{array}$ & $\begin{array}{c}\text { Chrysomphalus } \\
\text { dictiyospermi }\end{array}$ & $\begin{array}{c}\text { Aonidiella } \\
\text { aurantii }\end{array}$ \\
\hline Intrinsic rate of increase, $r_{m}$ & 0.120 & 0.061 & 0.041 \\
\hline Pseudo-rmij values & $0.12125 \pm 0.00695 \mathbf{a}$ & $0.06288 \pm 0.00769 \mathbf{b}$ & $0.04291 \pm 0.00754 \mathbf{b}$ \\
\hline Net production rate, $R_{0}$ & 36.027 & 12.520 & 6.600 \\
\hline Mean generation time, $T_{0}$ & 30.005 & 41.151 & 45.826 \\
\hline Total production rate $G R R$ & 125.542 & 65.111 & 41.369 \\
\hline Doubling time, $T 2$ & 5.803 & 11.286 & 16.832 \\
\hline Finite rates of increase, $\lambda$ & 1.127 & 1.063 & 1.042 \\
\hline$n$ & 64 & 52 & 50 \\
\hline
\end{tabular}

Different letters on the same line show a significant difference $(\mathrm{p}<0.05)$ 


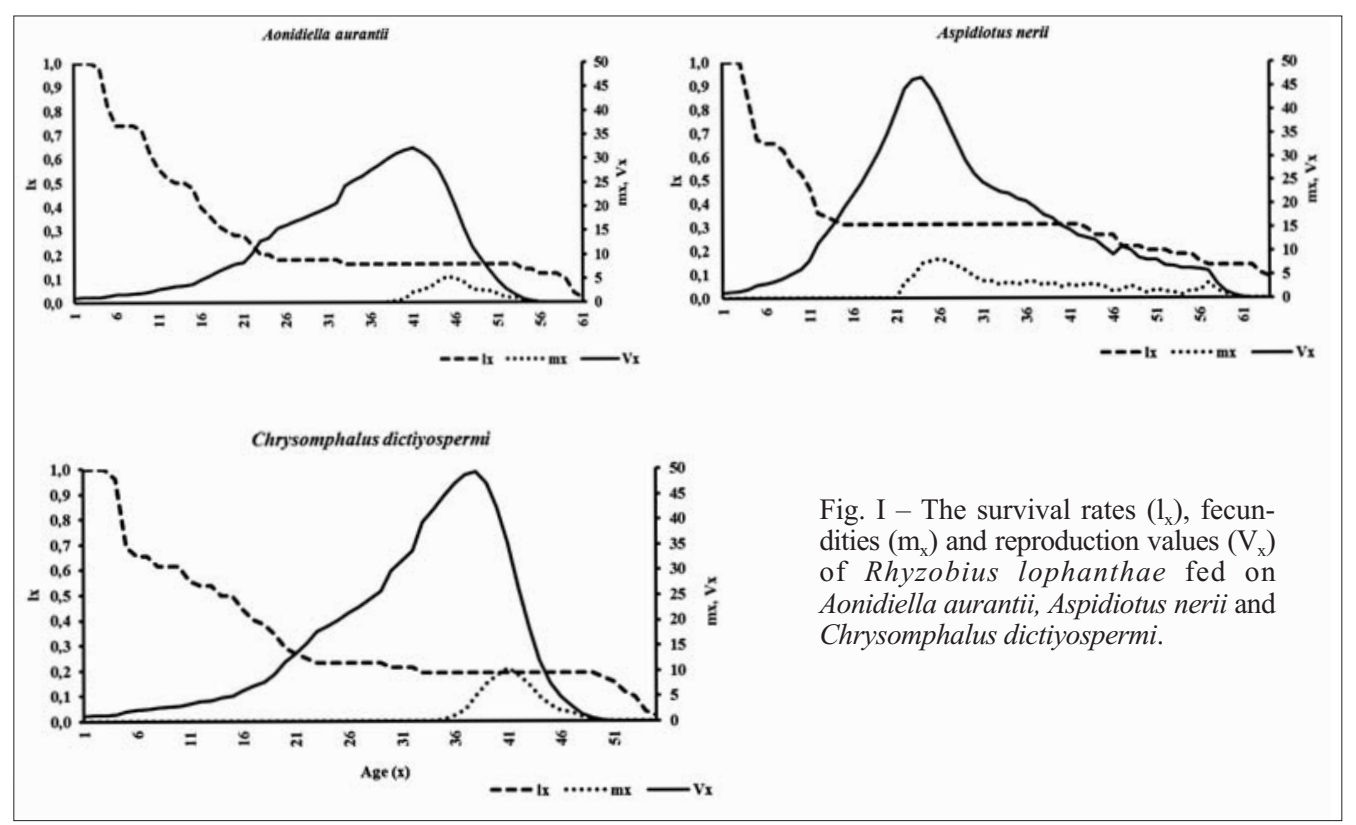

KaIRo M.T.K., Murphy S.T., 1995 - The life history of Rodolia iceryae Janson (Coleoptera: Coccinellidae) and the potential for use in innoculative releases against Icerya pattersoni Newstead (Homoptera: Margarodidae) on coffee. - Journal of Applied Entomology, 119: 487491.

Meyer J.S., Ingersoll C.G., Mcdonald L.L., Boyce M.S., 1986 - Estimating uncertainty in population growth rates: Jackknife vs. Bootstrap techniques. - Ecology, 67: 1156-1166.

Nar E., Ulusoy R. Ve Karaca İ., 2009 - Farkl Sicaklıkların Avcı Böcek, Rhyzobius lophantae Blaisdell (Coleoptera: Coccinellidae) 'nin Gelişmesi Üzerine Etkisi [Effect of Different Temperatures on the Development of Predator Insect, Rhyzobius lophantae Blaisdell (Coleoptera: Coccinellidae)]. Süleyman Demirel Üniversitesi, Fen Dergisi, 4 (1), 59-74.

ÖZGöKÇE M.S., Atlihan R., 2004 - Biological Features and Life Table Parameters of Mealy Plum Aphid, Hyalopterus pruni on Different Apricot Cultivars. Phytoparasitica, 33 (1):7-14.

ÖZGÖKÇE M.S., KARACA İ., 2010 - Yaşam Çizelgesi: Temel Prensipler ve Uygulamalar [Life Table: Basic Principles and Applications]. Türkiye Entomoloji Derneği 1. Çalıştayı, Ekoloji Çalışma Grubu, Isparta.

Pinder J.E., Wiener J.G., SMith M.H., 1978 - The Weibull distribution: a new method of summarizing survivorship data. - Ecology 59: 175-179.

StATHAS G.J., 2000 - The effect of temperature on the development of the predator Rhyzobius lophanthae and its phenology in Greece. - BioControl, 45 (4): 439-451.

STATHAS G.J., 2001 - Studies on morphology and biology of immature stages of the predator Rhzobius lophanthae Blaisdell (Col.: Coccinellidae).- Anzeiger für Schadlingskunde / Journal of Pest Science 74, 113-116.

Stathas G.J., Eliopoulos P.A., Kontodimas D.C., Tiamos D.TH., 2002 - Adult morphology and life cycle under constant temperatures of the predator Rhyzobius lophanthae Blaisdell (Col., Coccinellidae). - Anz. Schädlingskunde / Journal Pest Science 75, 105-109.

Stathas G.J., Kontodimas D.C., Bouras S.L., ECONOMOU L.P., 2005 - Life table parameters of Rhyzobius lophanthae Blaisdell (Coleoptera: Coccinellidae). Integrated Protection of Olive Crops, IOBC/WPRS Bulletin, 28 (9), 147-155.

SteINer H., 1962 - Metoden zur Untersuchungen des. Population dynamik in Obstanlangen. - Entomophaga, 7: 207-214.

Uygun N., Ulusoy M.R., Karaca İ., 2013 - Meyve ve Bağ Zararlilarl [Fruit and Vineyard Pests]. Cukurova Üniversitesi Ziraat Fakültesi Yayınları, Genel Yayın No: 252, Ders Kitapları Yayın No: A-81, 347s, Adana. 
